\title{
Hypophysectomy promotes gastric lesions in rats
}

\author{
MICHAEL N. GUILE \\ Northeastern State University, Tahlequah, Oklahoma
}

\begin{abstract}
Much research suggests that hypophysectomy renders an animal especially vulnerable to the effects of stress. In this experiment hypophysectomized rats were found to be much more susceptible to restraint-produced gastric lesions than were sham-operated controls $(4.5$ vs. 0 mean lesions). Concurrent behavioral measures of nociception did not distinguish between the two groups.
\end{abstract}

It has been reported that hypophysectomy has no effect on the formation of restraint-produced gastric lesions (Brodie \& Hanson, 1960; Hanson, 1963; Menguy, 1960). These results are surprising, considering the importance of the pituitary gland in the general adaptation syndrome (Selye, 1946, 1976). One would suspect that removal of the hypophysis would render an animal especially vulnerable to the effects of stress and that this vulnerability would be reflected in greater susceptibility to stress ulcers (cf. Selye, 1950, p. 697). Related research has focused on sensory and perceptual changes resulting from hypophysectomy. Hypophysectomy attenuates stressinduced analgesia resulting from immobilization (Amir \& Amit, 1979), cold water swim (Bodnar, Glusman, Brutus, Spiaggia, \& Kelly, 1979), insulin injections (Bodnar, Kelly, Mansour, \& Glusman, 1979), and intermittent footshock (Terman, Shavit, Lewis, Cannon, \& Liebeskind, 1984). Research on whether hypophysectomy affects nociception to electric shock has had mixed results. Gispen and colleagues (Gispen, van der Poel, \& van Wimersma Greidanus, 1973; Gispen, van Wimersma Greidanus, \& De Wied, 1970) have noted greater sensitivity in hypophysectomized rats to electric shock while others have observed no significant effects (Gibbs, Sechzer, Smith, Conners, \& Weiss, 1973; Rodgers \& Semple, 1978). This is an important issue because differential ulceration in hypophysectomized animals could be attributed to lowered pain thresholds, which result in greater stress. The purpose of this experiment was to examine the effects of hypophysectomy on ulcer formation in the rat while concomitantly taking behavioral indices of nociception.

\section{METHOD}

\section{Subjects}

The animals were 16 male Long-Evans rats (about 10 weeks old) from Blue Spruce Farms (Altamont, NY) with a mean body weight

A preliminary report based on this research was presented at the meeting of the Eastern Psychological Association, Philadelphia, April 1983. I thank Bruce Svare for doing the testosterone assays and John Broida, Bruce McCutcheon, and an anonymous reviewer for their comments on an earlier draft of this paper. Requests for reprints should be sent to Michael Guile, Psychology Department, Northeastern State University, Tahlequah, OK 74464. of $255.5 \mathrm{~g}$. They were housed individually in a room with a 12$\mathrm{h} / 12$-h light/dark cycle (lights on at 07:00). The rats were maintained ad lib on water, Wayne Lab-Blox, and $10 \%$ dextrose solution; however, all subjects were deprived of dry food $48 \mathrm{~h}$ prior to the start of the ulcer induction procedure. The animals did not receive any hormone replacement therapy.

\section{Apparatus and Procedure}

The rats were equally and randomly divided into hypophysectomized (hypox) and sham-operated groups. Under ether anesthesia, the hypophysis was removed by aspiration via the transauricular approach (Falconi \& Rossi, 1964). The hypophysis was reconstructed in a Petri dish at the time of the operation. Animals were given 10 to 14 days to recover. The rats were placed in Plexiglas restraint tubes that were $14 \mathrm{~cm}$ long and had an inside diameter of $5.08 \mathrm{~cm}$ (for greater details and a drawing of the restraint tubes see Guile \& McCutcheon, 1980). The rats were run with normal room illumination (fluorescent lights). After being restrained, but prior to attachment of tail electrodes, the two groups were tested for tailflick latencies (to the nearest $0.1 \mathrm{sec}$ ) to a radiant heat source. Pilot research with this procedure had demonstrated a mean $\pm \mathrm{SE}$ tailflick latency of $9.3 \mathrm{sec} \pm 0.5$ in nonoperated animals. During the $6 \mathrm{~h}$ of restraint, all rats were tested hourly for flinch and vocalization levels (in $\mathrm{mA}$ ) to electric shock delivered through tail electrodes. An ascending series method was used, starting at $0 \mathrm{~mA}$ and increasing in 0.25 -mA steps approximately every 20 to $25 \mathrm{sec}$ until the response occurred at two successive steps. The flinch and vocalization points for the trial were defined as the shock values that elicited the first response. These shocks were unsignaled. This behavioral measure of nociception has been used to measure signaled shock antinociception (Guile \& McCutcheon, 1984) and brain stimulation analgesia (McCutcheon \& Guile, 1980, 1984). At the end of $6 \mathrm{~h}$ a terminal blood sample was obtained by cardiac puncture with a heparinized syringe. Blood samples were immediately centrifuged for $22 \mathrm{~min}$ at $24,000 \mathrm{rpm}$. The plasma was then stored at $-20^{\circ} \mathrm{C}$ until assayed (Bartke, Steel, Musto, \& Caldwell, 1973) for testosterone. The stomachs were promptly removed and scored for number and cumulative length (in millimeters) of glandular stomach lesions. As an additional check on completeness of the hypophysectomies, seminal vesicles and testes were removed, blotted dry, and weighed to the nearest $1 \mathrm{mg}$. Two-tailed MannWhitney $U$ tests were performed on ulcer scores and tailflick latencies. Analyses of variance were performed on the flinch and vocalization data.

\section{RESULTS}

The results are presented in Table 1. There was no overlap between the lesion scores of the groups (Us = $0, \mathrm{p}<.001)$ and no significant difference with regard to tailflick latencies $(U=25, p>.2)$. Neither main effects nor interaction of hypophysectomy and repeated 
Table 1

Means and Standard Errors for Sham-Operated (Sham) and Hypophysectomized (Hypox) Groups

\begin{tabular}{lll}
\hline \multicolumn{1}{c}{ Dependent Variable } & \multicolumn{1}{c}{ Sham Group } & Hypox Group \\
\hline Lesion count* & $0 \pm 0$ & $4.5 \pm 1.4$ \\
Cumulative lesion length* & $0 \mathrm{~mm} \pm 0$ & $1.8 \mathrm{~mm} \pm 0.6$ \\
Tailflick latency & $9.8 \mathrm{sec} \pm 1$ & $10.8 \mathrm{sec} \pm 0.8$ \\
Flinch level & $0.24 \mathrm{~mA} \pm 0.02$ & $0.25 \mathrm{~mA} \pm 0$ \\
Vocalization level & $0.27 \mathrm{~mA} \pm 0.03$ & $0.28 \mathrm{~mA} \pm 0.4$ \\
Plasma testosterone* $\dagger$ & $1.35 \mathrm{ng} / \mathrm{ml} \pm 1$ & $0 \mathrm{ng} / \mathrm{ml} \pm 0$ \\
Seminal vesicle weight* & $251 \mathrm{mg} \pm 10.6$ & $67 \mathrm{mg} \pm 8.3$ \\
Testes weight* & $3.065 \mathrm{~g} \pm 0.07$ & $1.646 \mathrm{~g} \pm 0.13$ \\
\hline
\end{tabular}

*No overlap in scores between the groups. †Sensitivity is $10 \mathrm{pg}$.

measures were significant in the analyses of the flinch and vocalization nociceptive measures. Consequently, the results are collapsed into a single mean for each measure and group. The measurements reflecting completeness of the hypophysectomies (plasma testosterone, seminal vesicle weight, and testes weight) showed no overlaps between the hypophysectomized and the sham-operated rats.

\section{DISCUSSION}

Hypophysectomized rats were more vulnerable to restraint-induced gastric lesions than were sham controls. There were no significant differences between the two groups in nociception. The differences in plasma testosterone, seminal vesicle weight, and testes weight were consistent with complete hypophysectomies. The present gastric lesion results are in contast to previous experiments, which found negative results (Brodie \& Hanson, 1960; Menguy, 1960). The reasons for the difference in results are open to speculation. There are a myriad of differences between the present and previous studies, including the mode of restraint. Both Brodie and Hanson (1960) and Menguy (1960) literally wrapped their rats in wire mesh, affording them a much tighter fit (and corresponding greater degree of restraint) than was used in the present study (cf. Guile \& McCutcheon, 1980). This may account for the difference in results. For instance, $100 \%$ of Menguy's rats ulcerated in both the hypophysectomized group and the control group, suggesting a "ceiling effect." The rats in both groups may have been restrained so severely that it overwhelmed any hormonal differences between them.

The lack of differences in the measures of nociception between sham-operated and hypophysectomized animals corroborates similar findings elsewhere (Gibbs et al., 1973; Rodgers \& Semple, 1978). However, the interpretation of null results is problematical, particularly because research has demonstrated inconsistencies between tests for measuring analgesia (Brase, 1979; Kordower, Simone, Merrigan, \& Bodnar, 1981; Stern \& Kelly, 1981). One could ask the question, did both groups show analgesia, or did both fail to show analgesia? I would argue that the latter alternative is correct, inasmuch as the responses of the two groups remained at the lowest current settings over the course of the 6-h session. These results suggest that the large differences in ulcer scores are not due to differential pain thresholds between the two groups, which would affect their perception of the aversiveness of restraint (cf. Guile \& McCutcheon, 1984, for differences in ulcer scores concomitant with changes in nociception scores). Given these findings, it would be appropriate to examine hypophysectomy's direct effects on the stomach (e.g., Kyle, Clarke, Ward, Adesola, \& Welbourn, 1963; Robert, Phillips, \& Nezamis, 1966; Schapiro, Wruble, \& Britt, 1970; Taché, Goto, Gunion, Rivier, \& Debas, 1984) in the context of the present study.

\section{REFERENCES}

AMIR, S., \& AMIT, Z. (1979). The pituitary gland mediates acute and chronic pain responsiveness in stressed and non-stressed rats. Life Sciences, 24, 439-448.

Bartke, A., Steele, R. E., Musto, N., \& Caldwell, B. V. (1973). Fluctuations in plasma testosterone levels in adult male rats and mice. Endocrinology, 92, 1223-1228.

Bodnar, R. J., Glusman, M., Brutus, M., Spiaggia, A., \& Kelly, D. D. (1979). Analgesia induced by cold-water stress: Attenuation following hypophysectomy. Physiology \& Behavior, 23, 53-62.

Bodnar, R. J., Kelly, D. D., Mansour, A., \& Glusman, M. (1979). Differential effects of hypophysectomy upon analgesia induced by two glucoprivic stressors and morphine. Pharmacology Biochemistry \& Behavior, 11, 303-308.

BRASE, D. A. (1979). Roles of serotonin and $\gamma$-aminobutyric acid in opioid effects. In H. H. Loh \& D. H. Ross (Eds.), Advances in Biochemical Psychopharmacology: Vol. 18. Neurochemical Mechanisms of Opiates and Endorphins (pp. 409-428). New York: Raven Press.

BRODIE, D. A., \& HANSON, H. M. (1960). A study of the factors involved in the production of gastric ulcers by the restraint technique. Gastroenterology, 38, 353-360.

FALCoNI, G., \& Rossi, G. L. (1964). Transauricular hypophysectomy in rats and mice. Endocrinology, 74, 301-303.

Gibis, J., Sechzer, J. A., Smith, G. P., Conners, R., \& Weiss, J. M. (1973). Behavioral responsiveness of adrenalectomized, hypophysectomized, and intact rats to electric shock. Journal of Comparative and Physiological Psychology, 82, 165-169.

Gispen, W. H., van der Poel, A. M., \& van Wimersma GreidaNUS, T. J. B. (1973). Pituitary-adrenal influences on behavior: Responses to test situations with or without electric footshock. Physiology \& Behavior, 10, 345-350.

Gispen, W. H., van Wimersma Greidanus, TJ. B., \& De Wied, D. (1970). Effects of hypophysectomy and $\mathrm{ACTH}_{1-10}$ on responsiveness to electric shock in rats. Physiology \& Behavior, 5, 143-146.

Guile, M. N., \& McCutcheon, N. B. (1980). A tailshock-restraint technique for acute induction of gastric lesions in rats. Behavior Research Methods \& Instrumentation, 12, 359-360.

Guile, M. N., \& McCuTChEON, N. B. (1984). Effects of naltrexone and signaling inescapable electric shock on nociception and gastric lesions in rats. Behavioral Neuroscience, 98, 695-702.

Hanson, H. M. (1963). Restraint and gastric ulcers. Journal of Neuropsychiatry, 4, 390-395.

Kordower, J. H., Simone, D. A., Merrigan, K., Bodnar, R. J. (1981, April). Selective alterations in basal and analgesic pain thresholds following intraventricular and systemic parachlorophenylalanine (PCPA). Paper presented at the meeting of the Eastern Psychological Association, New York.

Kyle, J., Clarke, S. D., Ward, J. T., Adesola, A. O., \& Welbourn, R. B. (1963). The relationship of the major endocrine glands to experimental peptic ulceration. In S. C. Skoryna (Ed.), Pathophysiology of peptic ulcer (pp. 445-456). Philadelphia: Lippincott.

MCCutcheon, N. B., \& GuILE, M. N. (1980, April). ESB reduction of shock-restraint induced gastric lesions in rats. Paper presented at the meeting of the Eastern Psychological Association, Hartford, CT. McCutcheon, N. B., \& GuILE, M. N. (1984, April). Rewarding brain 
stimulation decreases stomach ulcers. Paper presented at the meeting of the Southwestern Psychological Association, New Orleans.

MengUY, R. (1960). Effects of restraint stress on gastric secretion in the rat. American Journal of Digestive Diseases, 5, 911-916.

Robert, A., Phillips, J. P., \& Nezamis, J. E. (1966). Gastric secretion and ulcer formation after hypophysectomy and administration of somatotrophic hormone. American Journal of Digestive Diseases, 11, 546-552.

RodGers, R. J., \& SEMPLE, J. M. (1978). Pituitary-adrenocortical axis and shock-induced fighting in rats. Physiology \& Behavior, 20, 533-537.

Schapiro, H., Wruble, L. D., \& Britt, L. G. (1970). The effect of hypophysectomy on the gastrointestinal tact: A review of the literature. Digestive Diseases, 15, 1019-1030.

SELYE, H. (1946). The general adaptation syndrome and the diseases of adaptation. Journal of Clinical Endocrinology, 6, 117-230.
Selye, H. (1950). Stress. Montreal: Acta, Inc.

Selye, H. (1976). The stress of life (rev. ed.). New York: McGraw-Hill. Stern, J., \& Kelly, D. D. (1981, April). The time course of stressinduced analgesia depends upon how pain thresholds are measured. Paper presented at the meeting of the Eastern Psychological Association, New York.

TACHÉ, Y., Goto, Y., Gunion, M., Rivier, J., \& Debas, H. (1984). Inhibition of gastric acid secretion in rats and in dogs by corticotrophinreleasing factor. Gastroenterology, 86, 281-286.

Terman, G. W., Shavit, Y., Lewis, J. W., Cannon, J. T., \& LieBESKIND, J. C. (1984). Intrinsic mechanisms of pain inhibition: Activation by stress. Science, 226, 1270-1277.

(Manuscript received February 12, 1985; revision accepted for publication July 16, 1985.) 